\title{
Preparation of Chitooligosaccharides from Chitosan using Crude Enzyme of Bacillus cereus D-11
}

\author{
Xing-Ai Gao $\cdot$ Yong-Feng Zhang $\cdot$ Ro-Dong Park $\cdot$ Xiao Huang $\cdot$ \\ Xin Ying Zhao $\cdot$ Jiao Xie $\cdot$ Rong-De Jin
}

Received: 28 December 2011 / Accepted: 1 February 2012 / Published Online: 31 March 2012

(C) The Korean Society for Applied Biological Chemistry 2012

\begin{abstract}
In order to enzymatically produce chitooligosaccharide using the crude enzyme preparation from Bacillus cereus D-11, we first studied the optimal reaction conditions. It was found that the optimal temperature for hydrolysis of chitosan was $55^{\circ} \mathrm{C}$. The ratio of enzyme/substrate should not be lower than $0.13 \mathrm{U} / \mathrm{mg}$ in the reaction mixture. The enzyme activity was stable below $50^{\circ} \mathrm{C}$. The products of enzymatic reaction were analyzed by both thin layer chromatography and high performance liquid chromatography. Under the appropriate condition, chitosan was hydrolyzed using the enzyme preparation. The resulting chitooligosaccharides were purified and separated by Dowex $\left(\mathrm{H}^{+}\right)$ion exchange chromatography. From $4 \mathrm{~g}$ soluble chitosan, $0.95 \mathrm{~g}(\mathrm{GlcN})_{2}$, $1.43 \mathrm{~g}(\mathrm{GlcN})_{3}$, and $1.18 \mathrm{~g}(\mathrm{GlcN})_{4}$ were recovered.
\end{abstract}

Keywords Bacillus cereus D-11 · chitooligosaccharides · crude enzyme $\cdot$ hydrolysis products

\section{Introduction}

Chitosan is insoluble in most solvents but is soluble in dilute organic acids. The use of chitosan is limited because of its insolubility in water, high viscosity, and tendency to coagulate with proteins at high $\mathrm{pH}$. In dilute aqueous acetic acid solution, the free amino groups of chitosan bond with $\mathrm{H}^{+}$to form $\mathrm{R}-\mathrm{NH}^{3+}$,

R.-D. Jin $(\varangle)$

Agricultural Environment and Resources Research Center, Jilin Academy of Agricultural Sciences, Changchun 130033, China

E-mail: rdkim2000@yahoo.com.cn

X.-A. Gao · Y.-F. Z. $\cdot$ X. Huang $\cdot$ X. Y. Zhao $\cdot$ J. Xie

Institute of Rural Energy, Jilin Academy of Agricultural Sciences, Changchun 130033, China

R.-D. Park

Division of Applied Bioscience and Biotechnology, Chonnam National University, Gwangju 500-757, Republic of Korea resulting in a soluble chitosan. When $\left[\mathrm{H}^{+}\right]$is low, the degree of $\mathrm{NH}_{2}$ protonation is also low. It is means the $\mathrm{pH}$ value of the solution should be selected in a proper range (Tian et al., 2003).

Chitosan oligosaccharides (COS) are bioactive compounds widely used in the fields of food, health care and agriculture. Several methods have been reported during the past few decades regarding the preparation of COS from chitosan, including enzymatic degradation and hydrolysis of chitosan through oxidation, UV, ultrasonication and irradiation. Among these methods, acid hydrolysis of chitosan is the most frequently used one for preparation of COS. The COS were obtained by $\mathrm{HCl}$ (Domard and Cartier, 1989), nitrous acid (Furusaki et al., 1996), phosphoric acid (Hasegawa et al., 1993) and hydrogen fluoride (Defaye et al., 1994) and $\mathrm{HNO}_{2}$ (Tommeraas et al., 2001) hydrolysis.

Alternatively, enzymatic hydrolysis of chitosan is regarded to be a potential method that can be instead of the chemical method in future. The enzymatic production of $\mathrm{COS}$ has been reported for few decades. Kuroiwa et al. (2002) studied the reaction conditions for effective production of pentamers and hexamers with enzyme preparation, and observed that it is greatly dependent on surface enzyme density, support particle size, temperature, aggregation speed, and initial substrate concentration.

Selection of suitable, highly active, and substrate-specific chitosanase for enzymatic hydrolysis of chitosan is important step without any doubt. On the other hand, after hydrolysis, selection of an effective method to separate the chitosan oligomers is also important. In this study, we tried to produce chitosan oligosaccharide using the crude enzyme preparation obtained from D-11.

\section{Materials and Methods}

Materials. Crude chitosanase and soluble chitosan preparation were obtained from the culture broth of $B$. cereus D-11 as described in Gao et al. (2008). Dialysis tubing cellulose (76 mm 
$\times 49 \mathrm{~mm}$ ) and Dowex $\left(\mathrm{H}^{+}\right.$from, Bio Rad Laboratories, Tokyo, Japan) 50WX4-200 ion exchange resin were purchased from Sigma-Aldrich. The chitosan oligomers were obtained from Wako Chemicals (Osaka, Japan).

Effect of enzyme amounts on production of COSs. $B$. cereus D11 was cultured in broth medium at $30^{\circ} \mathrm{C}$ for 3 days. The culture supernatant after centrifugation was dialyzed through a $0.5 \mathrm{kDa}$ cutting-off dialysis membrane. The resultant solution was used as the enzyme preparation for the following experiments. To assess the effect of enzyme amount on COSs production, $0.5-2 \mathrm{~mL}$ enzyme preparation $(7.5 \mathrm{U} / \mathrm{mL})$ was incubated with $2 \mathrm{~mL}$ of $2 \%$ soluble chitosan $(40 \mathrm{mg})$ in a total volume of $4 \mathrm{~mL}$ at $37^{\circ} \mathrm{C}$ for $30 \mathrm{~min}$. The reducing sugar was measured by DNS method (Miller, 1959).

Effect of temperature and thermal stability of chitosanase. For determination of optimal temperature, the reaction was carried out at various temperatures for $1 \mathrm{~h}$. For measurement of thermal stability, enzyme preparation was firstly incubated at various temperatures for $1 \mathrm{~h}$, and then it was incubated with soluble chitosan at $37^{\circ} \mathrm{C}$ for $30 \mathrm{~min}$.

COSs production using enzyme preparation. $200 \mathrm{~mL}$ of $2 \%$ soluble chitosan solution ( $\mathrm{pH} 5.5$ ) was incubated with $100 \mathrm{~mL}$ of chitosanase $(750 \mathrm{U})$ at $55^{\circ} \mathrm{C}$ for $18 \mathrm{~h}$. The reaction was terminated by heating at boiled water for $5 \mathrm{~min}$.

For separation of each COS produced from the enzymatic hydrolysis, $20 \mathrm{~mL}$ of reaction product were applied into a Dowex ion-exchange chromatograpy $(2.1 \times 50 \mathrm{~cm})$ which had been equilibrated with $1 \mathrm{~N} \mathrm{HCl}$. The column was eluted by a step-wise gradient of $\mathrm{HCl}$ solution from 1 to $4.5 \mathrm{~N}$. The fractions were collected in a coning tube $(15 \mathrm{~mL} /$ tube).

The separated chitosan oligomer from the column chromatography was pooled together and then concentrated under reduced pressure with a rotary vacuum evaporator. After that, it was precipitated in an ethanol solution $50 \%(\mathrm{v} / \mathrm{v})$ and then dried in a freeze dryer.

Analysis of COSs. The COS separated from the column was checked by a Ninhydrin method. From a fraction collector, $0.1 \mathrm{~mL}$ of COSs solution was taken and the $\mathrm{pH}$ was adjusted to neutral with $1 \mathrm{~N} \mathrm{NaOH}$ and then $1 \mathrm{~mL}$ of $0.2 \%$ Ninhydrin solution was added. After boring at $100^{\circ} \mathrm{C}$ for $20 \mathrm{~min}$, the mixture of each fraction was determined in terms of the absorbance at $570 \mathrm{~nm}$.

The COSs were checked by thin layer chromatography (TLC) (Jo et al., 2003). The amount of COSs in the reaction mixture was also analyzed by HPLC (model LC-10 AD, Shimadzu, Japan) (Gao et al., 2009).Amounts of oligosaccharides produced were calculated by comparing peak areas with those of the authentic chitosan oligomers.

\section{Results}

Effect of the enzyme amount on chitosan degradation. To investigate the effect of enzyme amount on the degradation of chitosan, $40 \mathrm{mg}$ of soluble chitosan was incubated with various amounts of crude enzyme $(7.5 \mathrm{U} / \mathrm{mL})$ at $37^{\circ} \mathrm{C}$ for $30 \mathrm{~min}$ in a total

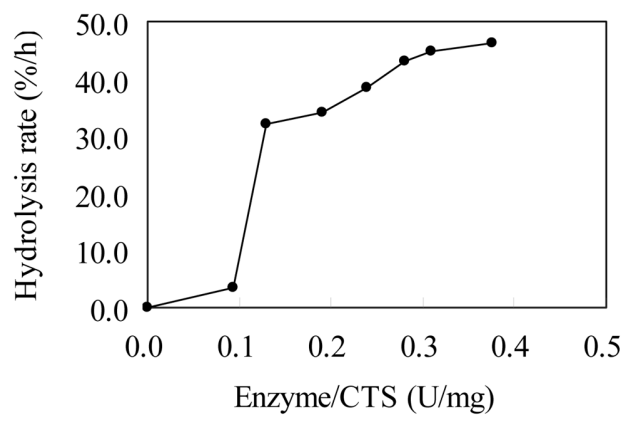

Fig. 1 Effect of enzyme amounts on the chitosan degradation. Various amounts of crude enzyme solutions were incubated with $2 \%$ soluble chitosan at $37^{\circ} \mathrm{C}$ for $30 \mathrm{~min}$.

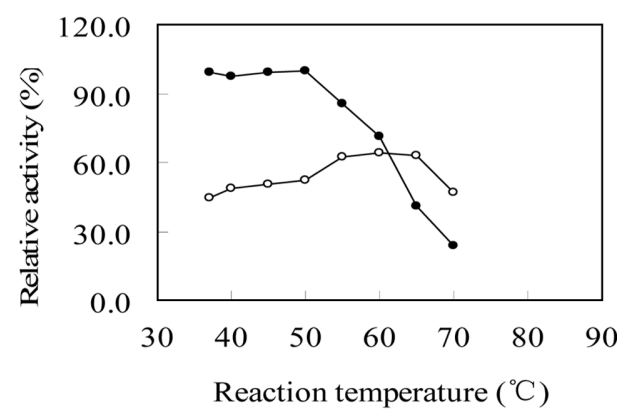

Fig. 2 Effects of temperature on activity and thermostability of the enzyme. The enzyme was preincubated at various temperatures for $1 \mathrm{~h}$ before enzyme reaction at $37^{\circ} \mathrm{C}$. $-\bigcirc$ - chitosanase activity; chitosanase thermostability.

volume of $4 \mathrm{~mL}$. The enzyme used in the reaction ranged from 0 15 Units. From the results shown in Fig. 1, it was found that the degradation of chitosan was very slow when lower than 5.25 Units of enzyme (or enzyme/chitosan ratio is $0.13 \mathrm{U} / \mathrm{mg}$ ) were incubated with $40 \mathrm{mg}$ soluble chitosan. The hydrolysis rate increased rapidly when the enzyme amount increased from 5.25 to 7.5 Units (or enzyme/chitosan ratio is 0.135 to 0.19 ). From 7.5 Units $(0.19 \mathrm{U} / \mathrm{mg})$, more enzyme amounts added in the reaction solution resulted in a slow increasing of the chitosan degradation rate.

Effect of temperatures on the degradation of chitosan. To understand the effect of temperature on the chitosan degradation, the enzyme reaction was carried out at various temperatures (37$70^{\circ} \mathrm{C}$ ) for $1 \mathrm{~h}$ (Fig. 2). The results showed that the highest hydrolysis rate was at a temperature range from $55-65^{\circ} \mathrm{C}$.

The thermostability of the enzyme was also studied. As shown in Fig. 2, the enzyme was stable below $50^{\circ} \mathrm{C}$. The enzyme activity lost dramatically at a temperature higher than $60^{\circ} \mathrm{C} .80 \%$ of the total enzyme activity lost at $70^{\circ} \mathrm{C}$ for $1 \mathrm{~h}$.

The enzyme reaction was carried out at various temperatures, leading to a different hydrolysis rate as shown in Fig 4. In addition, the products of enzyme reaction were analyzed by both TLC and HPLC. From the TLC results shown in Fig. 4, it was found that the products of enzyme reaction at $37-70^{\circ} \mathrm{C}$ were mainly composed of $(\mathrm{GlcN})_{2},(\mathrm{GlcN})_{3}$ and $(\mathrm{GlcN})_{4}$. The 


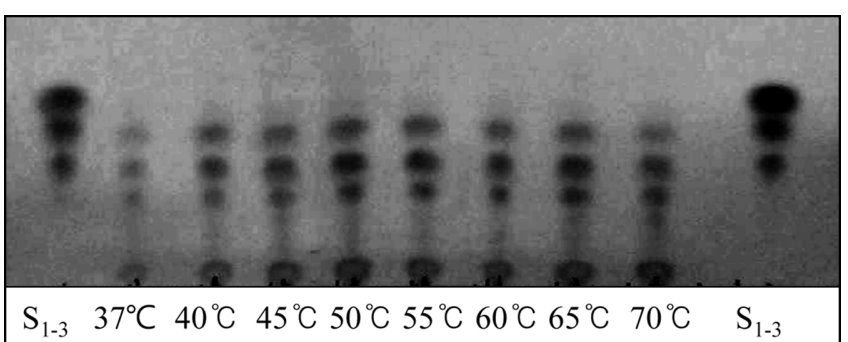

Fig. 3 TLC analysis of the products of enzyme reaction operated at various temperatures. Enzyme and substrate were incubated at various temperatures for $1 \mathrm{~h} . \mathrm{S}_{1-3}$ : standard of $(\mathrm{GlcN})_{1-3}$.

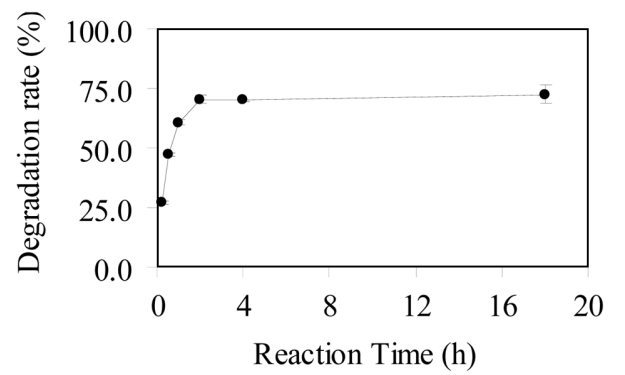

Fig. 4 Time course of degradation of chitosan by crude enzyme produced by $B$. cereus D-11.

temperatures did not affect the composition of the products. The highest amounts of $(\mathrm{GlcN})_{2},(\mathrm{GlcN})_{3}$ and $(\mathrm{GlcN})_{4}$ were achieved at $50-55^{\circ} \mathrm{C}$.

For a further quantification of the reaction products, HPLC analysis was carried out at various temperatures for $1 \mathrm{~h}$ (Table 1). Range of the hydrolysis rate was $48.4-76.0 \%$. The maximal production of total COSs was obtained at $55^{\circ} \mathrm{C}$. The composition of $(\mathrm{GlcN})_{2},(\mathrm{GlcN})_{3}$ and $(\mathrm{GlcN})_{4}$ were 13.2 , 32.6, and $30.2 \%$, respectively.

Time course of the degradation of chitosan. Fig. 4 showed the time course of chitosan degradation during $18 \mathrm{~h}$ at $55^{\circ} \mathrm{C}$. The reducing sugar released from the chitosan in the reaction solution increased with the increasing time during the first $2 \mathrm{~h}$. During the following reaction time, no significant degradation was found. For a further quantification of the reaction products, HPLC analysis was carried out at $55^{\circ} \mathrm{C}$ for various time interval (Table 2). A similar result with TLC analysis was found that production of $(\mathrm{GlcN})_{2},(\mathrm{GlcN})_{3}$ and $(\mathrm{GlcN})_{4}$ increased during the first $2 \mathrm{~h}$.
Table 1 HPLC analysis of the amount of hydrolysis products by D11 chitosanase

\begin{tabular}{crccc}
\hline \multirow{2}{*}{$\begin{array}{c}\text { Reaction } \\
\text { temperature } \\
\left({ }^{\circ} \mathrm{C}\right)\end{array}$} & \multicolumn{4}{c}{ Hydrolysis products (\%) } \\
\cline { 2 - 5 } & $(\mathrm{GlcN})_{2}$ & $(\mathrm{GlcN})_{3}$ & $(\mathrm{GlcN})_{4}$ & $\begin{array}{c}\text { Total } \\
(\mathrm{GlcN})_{2-4}\end{array}$ \\
\hline 37 & $8.0 \pm 1.5$ & $19.9 \pm 2.3$ & $20.5 \pm 4.5$ & 48.4 \\
40 & $9.0 \pm 2.5$ & $22.9 \pm 2.1$ & $18.1 \pm 3.5$ & 50.0 \\
45 & $15.9 \pm 2.2$ & $27.2 \pm 4.5$ & $27.8 \pm 2.4$ & 70.9 \\
50 & $17.3 \pm 3.0$ & $24.2 \pm 3.4$ & $27.6 \pm 4.1$ & 69.2 \\
55 & $13.2 \pm 1.3$ & $32.6 \pm 0.9$ & $30.2 \pm 2.3$ & 76.0 \\
60 & $7.6 \pm 4.5$ & $28.3 \pm 2.2$ & $26.5 \pm 3.3$ & 62.4 \\
65 & $6.0 \pm 3.9$ & $24.7 \pm 1.3$ & $24.1 \pm 4.1$ & 54.8 \\
70 & $4.1 \pm 5.4$ & $20.0 \pm 0.7$ & $24.1 \pm 3.2$ & 48.2 \\
\hline
\end{tabular}

From 2 to $18 \mathrm{~h}$, little further degradation was found. The amounts of $(\mathrm{GlcN})_{2},(\mathrm{GlcN})_{3}$ and $(\mathrm{GlcN})_{4}$ in the degradation products were $14.0,36.8$, and $21.7 \%$ after $2 \mathrm{~h}$, respectively. In addition, the HPLC results also showed that a few amounts of $(\mathrm{GlcN})_{5}$ produced during the first $15 \mathrm{~min}$ and the $(\mathrm{GlcN})_{5}$ was soon degraded to smaller COSs.

Purification of COSs enzymatically produced from soluble chitosan. To obtain the COSs, a mixture of $200 \mathrm{~mL}$ of $2 \%$ soluble chitosan and $100 \mathrm{~mL}$ of dialyzed chitosanase (750 U) (or enzyme/ chitosan ratio is $0.1875 \mathrm{U} / \mathrm{mg}$ ) was incubated for $18 \mathrm{~h}$ at $55^{\circ} \mathrm{C}$, and then boiled for $5 \mathrm{~min}$. The hydrolysis products $(\mathrm{GlcN})_{2}$, $(\mathrm{GlcN})_{3}$ and $(\mathrm{GlcN})_{4}$ was separated by Dowex $\left(\mathrm{H}^{+}\right)$ion-exchange chromatography. The products were separated into three main peaks, as shown in Fig. 5, named by A, B, and C, respectively. To confirm the composition of these peaks, TLC and HPLC analysis were carried out. The products obtained from the three peaks 26 $35,37-46$, and 50-59 are $(\mathrm{GlcN})_{2},(\mathrm{GlcN})_{3}$, and $(\mathrm{GlcN})_{4}$, respectively (Fig. 6). The composition of each peak was also confirmed by reverse-phase HPLC on TSK gel $\mathrm{NH}_{2}-60$ column. (Data not shown).

To concentrate each $\mathrm{COS}, \mathrm{A}, \mathrm{B}$, and $\mathrm{C}$ were separately dissolved in ethanol, which was evaporated to dryness under the reduced pressure at $60^{\circ} \mathrm{C}$. This operation was repeated twice to completely remove residual $\mathrm{HCl}$. The resulting $\mathrm{COSs}$ were lyophilized and then conserved in a $\mathrm{P}_{2} \mathrm{O}_{5}$ containing desiccators. Finally, A, B, and C corresponding to $(\mathrm{GlcN})_{2},(\mathrm{GlcN})_{3}$, and $(\mathrm{GlcN})_{4}$ were weighted to be $0.945,1.427$, and 1.183 , respectively (Table 3).

Table 2 HPLC analysis of the hydrolysis products of chitosan by B. cereus D-11 chitosanase during different incubation time

\begin{tabular}{crrrrr}
\hline \multirow{2}{*}{ Reaction time $(\mathrm{h})$} & \multicolumn{3}{c}{ Hydrolysis products $(\%)$} \\
\cline { 2 - 6 } & $(\mathrm{GlcN})_{2}$ & $(\mathrm{GlcN})_{3}$ & $(\mathrm{GlcN})_{4}$ & $3.1 \pm 1.8$ & \multicolumn{1}{c}{ Total $(\mathrm{GlcN})_{2-4}$} \\
\hline 0.25 & $2.2 \pm 0.5$ & $6.8 \pm 1.7$ & $8.9 \pm 0.9$ & 0 & 21.1 \\
0.5 & $4.9 \pm 1.2$ & $14.7 \pm 1.5$ & $15.3 \pm 1.0$ & 0 & 34.9 \\
1 & $7.2 \pm 2.3$ & $20.2 \pm 1.2$ & $19.2 \pm 2.0$ & 0 & 46.6 \\
2 & $14.0 \pm 0.4$ & $36.8 \pm 2.9$ & $21.7 \pm 2.1$ & 0 & 72.5 \\
4 & $16.2 \pm 2.1$ & $38.9 \pm 3.1$ & $23.6 \pm 0.3$ & 0 & 8.7 \\
\hline
\end{tabular}




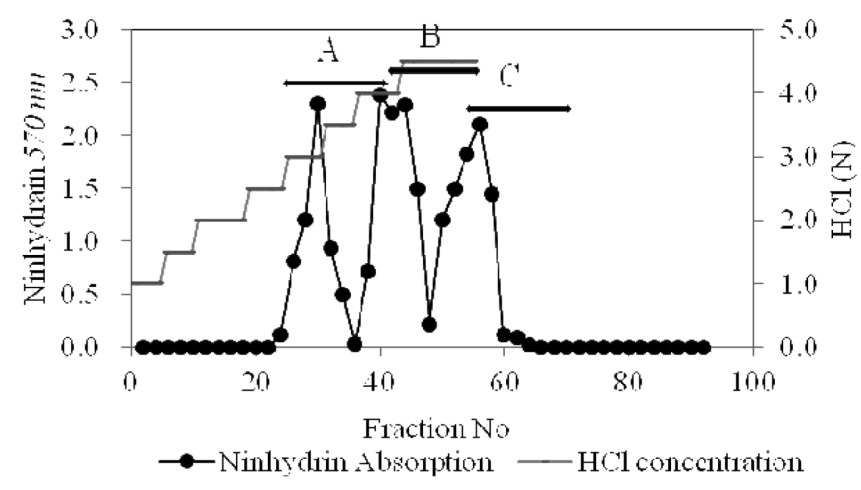

Fig. 5 Elution patterns of chitosan samples from Ion-exchange column and the column was eluted with a linear gradient of $\mathrm{HCl}$ from 1 to $4.5 \mathrm{~N}$ by Ninhydrin method. $\mathrm{A}, \mathrm{B}$, and $\mathrm{C}$ indicate the fractions pooled.

\section{Discussion}

In this study, for a maximal production of COSs from chitosan, we investigated the optimal conditions, including the optimal temperature and thermostability of this enzyme, the optimal incubation time and the enzyme amounts required. The optimal temperature was determined to be $55^{\circ} \mathrm{C}$ and the enzyme was stable below $50^{\circ} \mathrm{C}$. A longer reaction time resulted in a higher degradation, however, it seemed that during the first $2 \mathrm{~h}$, most of the chitosan have been degraded into COSs which could not be further degraded even though a longer reaction time was given. The enzyme amounts required for an effective degradation of chitosan have also been studied. The results indicated that the ratio of enzyme/substrate should not be lower than $0.13 \mathrm{U} / \mathrm{mg}$ in the reaction mixture. Kuo et al. (2004) reported that using a crude chitosanase from B. cereus NTU-FC-4, the highest enzyme/ substrate $(\mathrm{E} / \mathrm{S})$ ratio used for the hydrolysis of degree of deacetylation (DDA) $66 \%$ chitosan was set at $0.2 \mathrm{U} / \mathrm{mg}$ in the system.

From the time course of the enzymatic degradation of soluble chitosan, it was found that the hydrolysis rate was very fast during the first $2 \mathrm{~h}$. And in the following reaction time, no significant change occurred, suggesting that the enzyme was an endo-type
Table 3 Yield of COSs purified from ion-exchange chromatography

\begin{tabular}{ccc}
\hline$(\mathrm{GlcN})_{\mathrm{n}}$ & Yield $(\mathrm{g})$ & Hydrolysis rate $(\%)$ \\
\hline$(\mathrm{GlcN})_{2}$ & 0.95 & 23.63 \\
$(\mathrm{GlcN})_{3}$ & 1.43 & 35.69 \\
$(\mathrm{GlcN})_{4}$ & 1.18 & 29.58 \\
Total $(\mathrm{GlcN})_{2-4}$ & 3.56 & 88.89 \\
\hline
\end{tabular}

enzyme which hydrolyzed the enzyme in an endo-type very fast in the beginning. The TLC and HPLC analysis results indicated that the products were composed of $(\mathrm{GlcN})_{2},(\mathrm{GlcN})_{3}$ and $(\mathrm{GlcN})_{4}$ even though a prolonged time was allowed. However, it seemed that $(\mathrm{GlcN})_{5}$ produced at very early stage would be further egraded into $(\mathrm{GlcN})_{2}$ and $(\mathrm{GlcN})_{3}$ because $(\mathrm{GlcN})_{5}$ occurred at $15 \mathrm{~min}$ was not observed at $30 \mathrm{~min}$ or a longer time.

From $4 \mathrm{~g}$ of chitosan sample, a final yield 23.63, 35.69, and $29.58 \%(\mathrm{GlcN})_{2},(\mathrm{GlcN})_{3}$ and $(\mathrm{GlcN})_{4}$ were obtained, respectively. These results were compared with the previously reported acid hydrolysis method where the final yield $11.6 \%$ of $(\mathrm{GlcN})_{1}, 28.8 \%$ of $(\mathrm{GlcN})_{2}, 28.1 \%$ of $(\mathrm{GlcN})_{3}, 8.4 \%$ of $(\mathrm{GlcN})_{4}, 8.0 \%$ of $(\mathrm{GlcN})_{5}$, and $4.7 \%$ of $(\mathrm{GlcN})_{6}$ were obtained at $24 \mathrm{~h}$ reaction (Lee et al, 1999). This suggested that our chitosanase could more effectively degrade chitosan than the chemical method.

In addition, our chitosanase was compared with other reported ones on degradation of chitosan. For instance, Kuo et al. (2004) reported a crude chitosanase from $B$. cereus NTU-FC-4, which hydrolyzed chitosan of DDA $66 \%$ in batch reactor and membrane reactor to continuously produce chitooligosaccharides. The yield obtained by this technique was 75 and $99.9 \%$ of total amount of $(\mathrm{GlcN})_{2-6}$, respectively. And Izume and Ohtakara (1987) reported COSs from $(\mathrm{GlcN})_{2-5}$ can be prepared by enzymatic hydrolyzate of chitosan with a recovery above $60 \%$.

Finally, we concluded that $\mathrm{COS}(\mathrm{GlcN})_{2},(\mathrm{GlcN})_{3}$, and $(\mathrm{GlcN})_{4}$ could be prepared with a good yield by an enzymatic production process by $B$. cereus D-11 chitosanase as well as a purification step applying the Dowex ion exchange chromatography.

Acknowledgment This study was supported by a grant from the International Science and technology cooperation project (Code\#20120755), Jilin Provincial Science \& Technology Department, China.

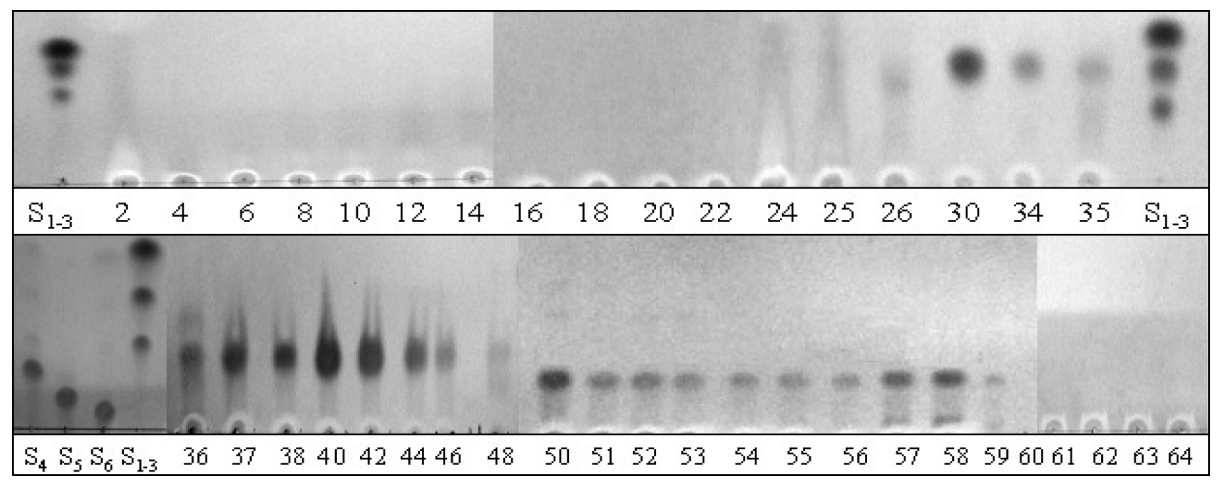

Fig. 6 TLC analysis of fractions from ion-exchange chromatography. S1-6: standard of COSs. 


\section{References}

Defaye J, Adelle A, and Pedersen C (1994) A convenient access to $\beta$-(1-4)linked 2-amino-2-deoxy-D-glucopyranosyl fluoride oligosaccharides and $\beta$-(1-4)-linked 2-amino-2-deoxy-D-glucopyranosyl oligosaccharides by fluorolysis and fluorohydrolysis of chitosan. Carbohydr Res 261, 267277.

Domard A and Cartier N (1989) Chitooligosaccharides: 1. Preparation and characterization. Int J Biol Macromol 11, 297-302.

Furusaki E, Ueno Y, Sakairi N, Nishi N, and Tokura S (1996) Facile preparation and inclusion ability of a chitosan derivative bearing carboxymethyl- $\beta$-cycodextrin. Carbohydr Polym 29, 29-34.

Gao XA, Ju WT, Jung WJ, and Park RD (2008) Purification and characterization of $41-\mathrm{kDa}$ chitosanase from Bacillus cereus D-11. Carbohydr Polym 3, 513-520.

Gao XA, Jung WJ, Kuk JH, and Park RD (2009) Reaction pattern of Bacillus cereus D-11 chitosanase on chitooligosaccharide alcohols. J Microbiol Biotechnol 4, 358-361.

Hasegawa M, Isogai A, and Onabe F (1993) Preparation of low-molecularweight chitosan using phosphoric acid. Carbohydr Polym 20, 279-283.

Izume I and Ohtakara A (1987) Preparation of D-glucosamine oligosaccharides by the enzymatic hydrolysis of chitosan. Agric Biol
Chem 51, 1189-1191.

Jo YY, Jo KJ, Jin YL, Jung WJ, Kuk JH, Kim KY, Kim TH, and Park RD (2003) Characterization of endo chitosanase-producing Bacillus cereus p16. J Microbiol Biotechnol 13, 960-968.

Kuo CH, Chen CC, and Chiang BH (2004) Process characteristics of hydrolysis of chitosan in a continuous enzymatic membrane reactor. $J$ Food Sci 69, 332-337.

Kuroiwa T, Ichikawa S, Hiruta O, Sato S, and Mukataka S (2002) Factors affecting the composition of oligosaccharides produced in chitosan hydrolysis using immobilized chitosanases. Biotechnol Prog 18, 969 974.

Lee MY, Yar F, Shin-ya Y, Kajiuchi T, and Yang JW (1999) Optimum conditions for the precipitation of chitosan oligomers with DP 5-7 in concentrated hydrochloric acid at low temperature. Process Biochem 34, 493-500.

Miller GL (1959) The use of dinitrosalicylic acid reagent for the determination of reducing sugars. Anal Chem 31, 426-428.

Tian F, Liu Y, Hu K, and Zhao BY (2003) The depolymerization mechanism of chitosan by hydrogen peroxide. J Mater Sci 38, 4709-4712.

Tommeraas K, Varum KM, Christensen BE, and Smidrod O (2001) Preparation and characterization of oligosaccharides produced by nitrous acid depolymeriation of chitosans. Carbohydr Res 333, 137-144. 